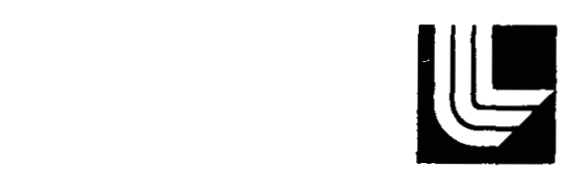

LAWRENCE LIVERMORE LABORATORY

University of Calfomia, Livermore, California, 94550

UCRL -51977

\title{
POSSIBILITIES FOR CONTROLLING HEAVY METAL SULFIDES IN SCALE FROM GEOTHERMAL BRINES
}

Donald D. Jackson

John H. Hi11

January 19,1976

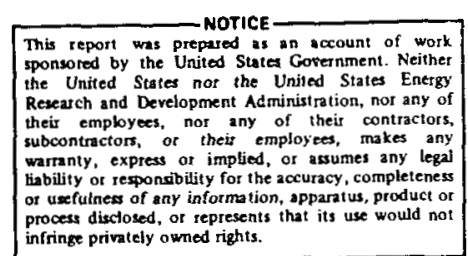




\section{DISCLAIMER}

This report was prepared as an account of work sponsored by an agency of the United States Government. Neither the United States Government nor any agency Thereof, nor any of their employees, makes any warranty, express or implied, or assumes any legal liability or responsibility for the accuracy, completeness, or usefulness of any information, apparatus, product, or process disclosed, or represents that its use would not infringe privately owned rights. Reference herein to any specific commercial product, process, or service by trade name, trademark, manufacturer, or otherwise does not necessarily constitute or imply its endorsement, recommendation, or favoring by the United States Government or any agency thereof. The views and opinions of authors expressed herein do not necessarily state or reflect those of the United States Government or any agency thereof. 


\section{DISCLAIMER}

Portions of this document may be illegible in electronic image products. Images are produced from the best available original document. 


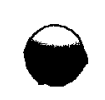

\section{Contents}

Abstract . . . . . . . . . . . . . . . . . . . . . 1 Introduction . . . . . . . . . . . . . . . . . . . . . . . 1

Scale-Forming Reactions . . . . . . . . . . . . . . . . . 3

Influence of Oxidation State . . . . . . . . . . . . . . 6

Oxidation of Sulfur-Containing Species . . . . . . . . . . . . . 7

Solubilities of Copper and Iron Compounds . . . . . . . . . . . . . . . 11

Solubilities of Barium and Calcium Compounds . . . . . . . . . . . . . . 11

Summary . . . . . . . . . . . . . . . . . . . . . . . . 12

References . . . . . . . . . . . . . . . . . . . 13 


\section{POSSIBILITIES FOR CONTROLLING \\ HEAVY METAL SULFIDES \\ IN SCALE FROM GEOTHERMAL BRINES}

\section{Abstract}

Heavy metal sulfides form a substantial part of the scale solids depositing from high-temperature, high-saline geothermal brines. An assessment has been made of the prospects for controlling this deposition by chemical modification of the brine.

An outline is given of the types of reactions influencing sulfide precipitation. It is suggested that two factors affecting sulfide solubility and that are amenable to chemical modification of the brine are oxidation state and $\mathrm{pH}$. A partial oxidation process can be used to convert aqueous sulfide species to free sul- fur, a process favored by thermodynamics and kinetics. Some oxidizing agents are suggested for this purpose.

A discussion is given of the possibilities of precipitating other solid phases after extensive oxidation. It is concluded on the basis of the available data that this possibility exists, but that uncertainties in reaction kinetics, unavailable data, and solution complexity make an exact analysis difficult. The usefulness of a field evaluation of chemical modification processes is indicated.

\section{Introduction}

The high rate of accumulation of solids from flowing geothermal brines on cooling and pressure release presents a major problem for energy extraction processes. There are several general types of procedures that have been considered for scale contro1:
- Chemical or electrical modification of the fluid to prevent or slow precipitation.

- F1uid pretreatment to remove particulates.

- Hardware surface treatment to prevent adhesion.

- Mechanical or chemical removal. 
There are unresolved technical or economic problems in all of these areas. In this study we will consider chemical modification as a possible means for reducing the deposition rate of heavy metal su1fides, a specific type of material that occurs abundantly in scale from high saline brines. Unfortunately, the complexity of the brine, kinetic factors, and lack of experimental work under carefully controlled conditions have limited the understanding of the scaling process, and we are compelled to speculate on the mechanisms involved.
Scale is formed by two types of reactions taking,place concurrently as the pressure and temperature of the brine are reduced. The first reaction is the precipitation of amorphous silica, a temperaturesolubility process strongly modified by kinetics. Owen ${ }^{1}$ has discussed the relation of this somewhat unusual deposition process to other better understood reactions in the chemistry of silica. It is evidently a process of gel formation from a hot, rapidly flowing system.

The second type of reaction is the precipitation and crystallization of

Table 1. Selected properties of geothermal brines. ${ }^{a}$

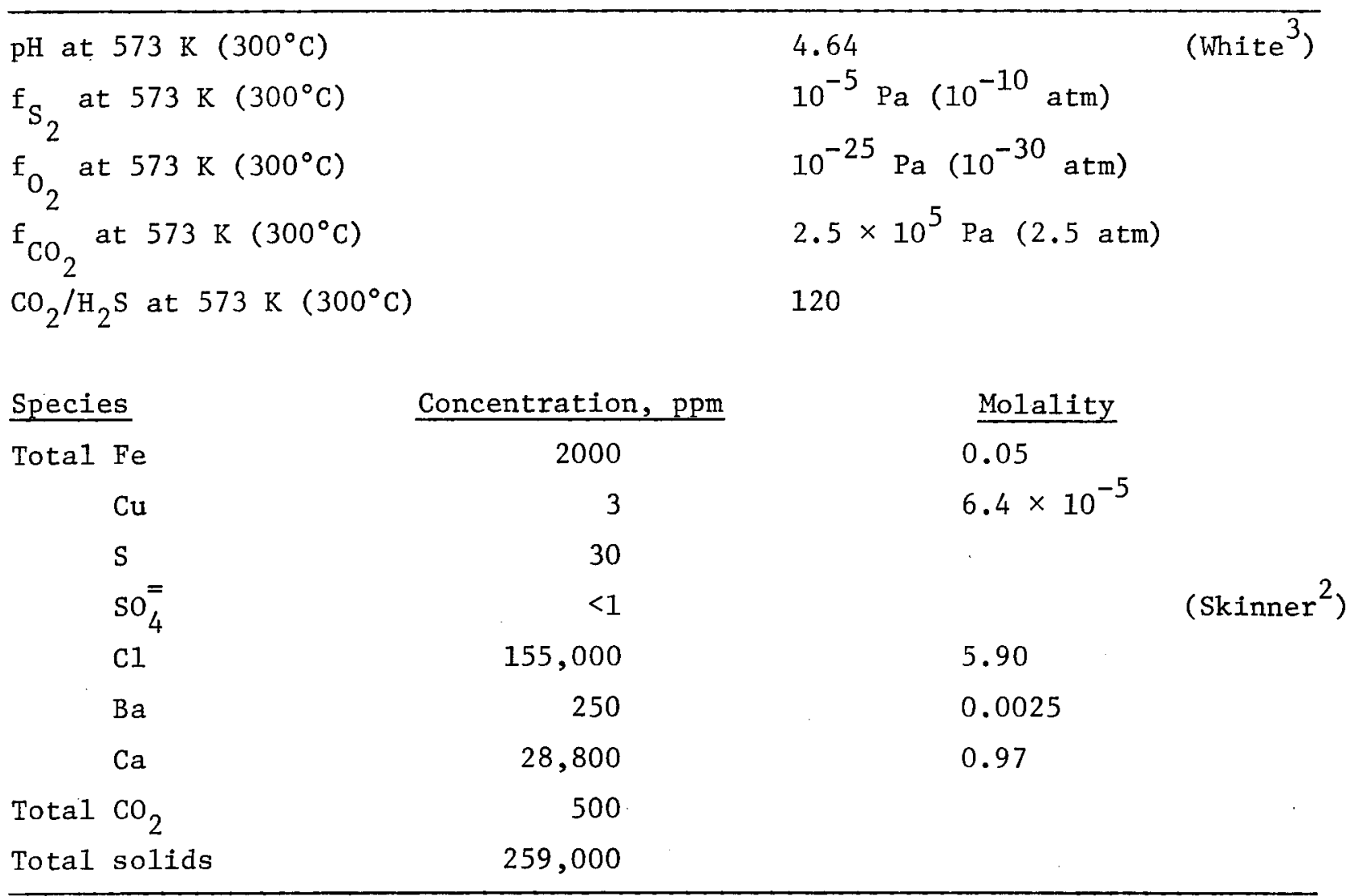

a Data is from Helgeson, Ref. 4, for well IID \#2, except as noted. 
sulfide minerals, especially those of iron and copper. The exact role played by these elements in the deposition of silica, which is the cominant scale-forming process, is uncertain. However, because of the well-known effects of metal ions in the aggregating reactions of silica, it is suspected that metals like aluminum, iron, and copper found in scale have promoted the joining of silica sol particles to form a rigid gel structure. The formation of strong sulfur-copper and sulfur-iron bonds during this process would then be responsible for the great extent to which sulfur is concentrated in scale. The occurrence of part of the iron, copper, and sulfur in scale in the form of crystallites does not necessarily indicate a mechanism of direct crystallization from solution, as hypothesized by Skinner. ${ }^{2} \mathrm{He}$ showed that much of the iron and sulfur in such scale is not present as sulfides. However, it is possible that crystal formation might also result from a diffusion process in the silica gel matrix. At any rate, a reduction in the mass of scale
Table 2. Sulfide and associated minerals from Salton Sea area brines.

\begin{tabular}{ll}
\hline $\mathrm{Cu}_{5} \mathrm{FeS}_{4}$ & Bornite \\
$\mathrm{Cu}_{9} \mathrm{~S}_{5}$ & Digenite \\
$\mathrm{CuFeS}_{2}$ & Chalcopyrite \\
$\mathrm{CuAgS}$ & Stromeyerite \\
$(\mathrm{Cu}, \mathrm{Fe}){ }_{12} \mathrm{Sb}_{4} \mathrm{~S}_{13}$ & Tetrahedrite \\
$\mathrm{FeS}_{2}$ & Pyrite \\
$\mathrm{FeAsS}_{\mathrm{Ag}}$ & Arsenopyrite \\
$\mathrm{Cu}_{2} \mathrm{~S}$ & Metallic silver \\
$\mathrm{SiO}_{2}$ & Chalcocite \\
\hline
\end{tabular}

deposited (by the removal of sulfides) is desirable in itself. If sulfur plays a central role in the silica cementation process, then a reduced silica deposition rate could also result.

The summary of properties of the Salton area brines in Table 1 will be useful in discussing the possibilities for chemical modification.

The principal sulfide and associated minerals found in scale $e^{2}$ are listed in Table 2. Not all of these phases are found in all scale samples from all wells in the area, but appear in various combinations.

\section{Scale-Forming Reactions}

Reactions (1) through (8) in

Fig. 1 make up a schematic diagram of processes that could influence the precipitation of scale-forming elements, illustrated here by $\mathrm{Cu}_{2} \mathrm{~S}$. Note that these reactions do not 
(1)

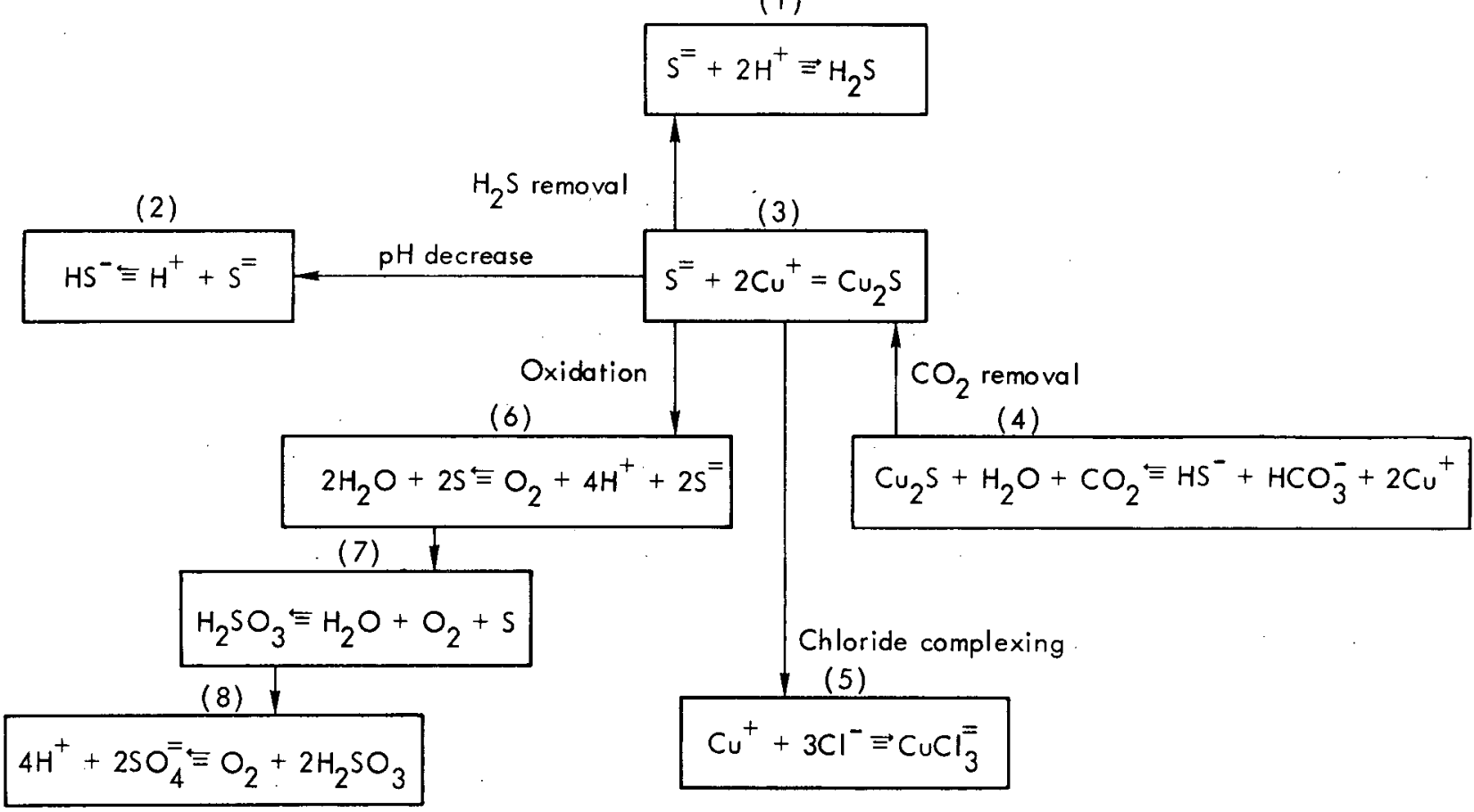

Fig. 1. Schematic diagram of typical reactions in sulfide scale formation.

completely define the chemical system. They were selected arbitrarily from a maze of interactions that cannot be illustrated very well. However, the principles remain the same, and these simple mass-action considerations may lead to some useful conclusions.

The critical reaction is the precipitation equilibrium (3), for which the ion product is known. ${ }^{5}$ However, any other processes, such as those of Fig. 1 affecting the activities of $\mathrm{Cu}^{+}$and $\mathrm{S}^{=}$, will determine whether enough are present to exceed this product and precipitate in the scale silica matrix. In other words, copper and sulfur can be "stored" in many species whose number and stabilities determine the actual concentrations of the simple ions. Chloride complexing reactions such as (5) are of particular importance. The solubility relationships for many of the scale sulfides have been estimated for $\mathrm{NaCl}$ solutions, ${ }^{6}$ as shown in Fig. 2, and are useful as approximations for natural geothermal brines.

In such brines, of course, other reactive species exist that may alter its precipitation behavior. For example, reaction (4) indicates that a pressure release that resulted in 
the formation of gaseous $\mathrm{CO}_{2}$ could in itself encourage precipitation, even if equilibrium were maintained. This effect has been observed in samples taken from the Sinclair \# 4 we11. 7

Reactions (1), (2), and (6) through (8) are processes by which the activity of $\mathrm{S}$ can be reduced through conversion to other species, effectively enhancing the solubility of $\mathrm{Cu}_{2} \mathrm{~S}$.

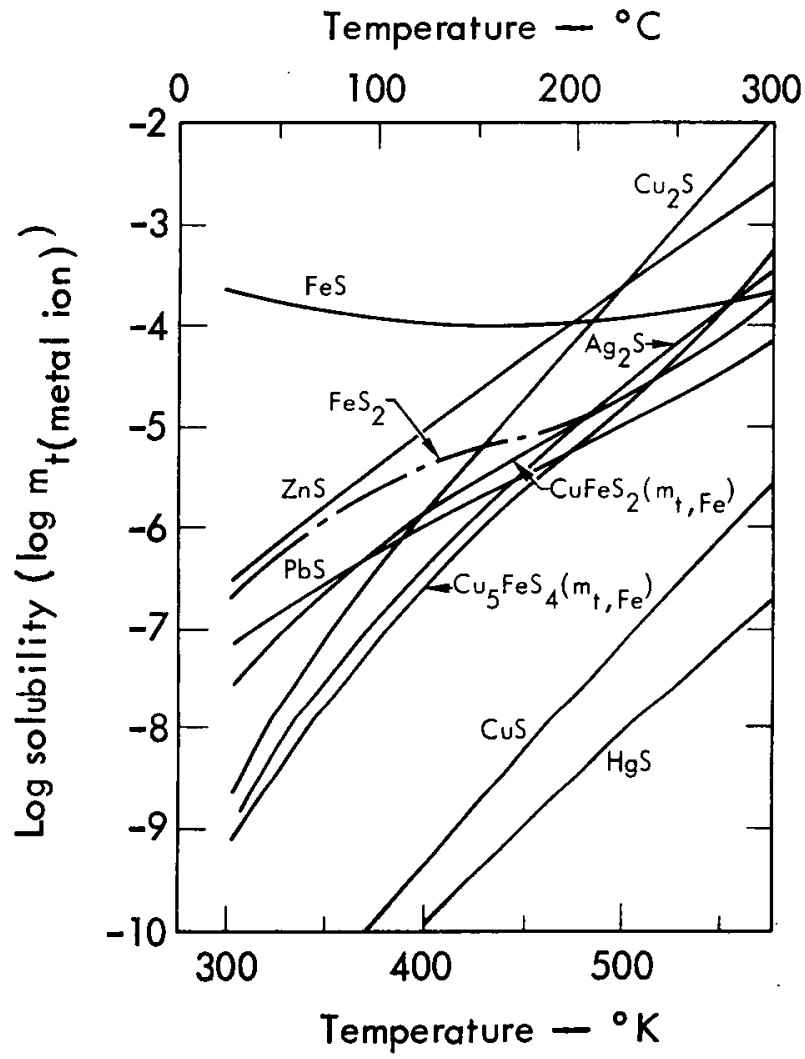

Fig. 2. Solubilities of sulfides in $3 \mathrm{M} \mathrm{NaC1}$.
In the following discussion, relationships in the brine will be considered at $523 \mathrm{~K}\left(250^{\circ} \mathrm{C}\right)$. This is close to the expected temperature at a wellhead, where the brine is most accessible for chemical modification. It is likely that precipitation and scale formation have already started at this point, but they do not appear to become severe until the rapid changes in conditions encountered during cooling and expansion.

It should be recognized that the available data for neither the natural brine system nor the properties of its components are very accurate. We may, therefore, expect to arrive only at a qualitative understanding of the precipitation processes. The most extensive estimation and tabulation of thermodynamic properties of hightemperature aqueous species in hydrothermal solutions is that of Helgeson, ${ }^{6}$ and much use will be made of this data.

Another assumption that has been made is that differences in the properties of brines produced from different wells in the area and at different times are negligible. 


\section{Influence of Oxidation State}

The brine is a reducing medium as indicated in Table 1 by the low oxygen fugacity and the appearance of small amounts of $\mathrm{H}_{2} \mathrm{~S}$ in the gas produced.

The fact that both free silver and silver sulfides are found in scales from the Salton area allows us to estimate, in another way, how reducing the brines are. The system $\mathrm{Fe}-\mathrm{Cu}-\mathrm{Ag}-\mathrm{S}$ is known to be complex, ${ }^{8}$ and rapid reactions even at low temperatures after the scale is deposited tend to make identification of the original precipitates difficult. However, the CuAgS appears to have originated from $\mathrm{Ag}_{2} \mathrm{~S}$ in solid solution in other sulfides, ${ }^{2}$ and the metallic silver appears to have been an equilibrium component of the mineral assemblage formed. Assuming unit activities in the solid phases, we are then able to evaluate reaction (9).

$$
\begin{aligned}
\mathrm{Ag}_{2} \mathrm{~S}(\mathrm{~s})+ & \mathrm{H}_{2} \mathrm{O}(\mathrm{g})=2 \mathrm{Ag}(\mathrm{s}) \\
& +\mathrm{H}_{2} \mathrm{~S}(\mathrm{~g})+\frac{1}{2} \mathrm{O}_{2}(\mathrm{~g}) .
\end{aligned}
$$

If we use the $\mathrm{CO}_{2} / \mathrm{H}_{2} \mathrm{~S}$ ratio and $\mathrm{CO}_{2}$ fugacity of Table 1 as approximately valid at $523 \mathrm{~K}\left(250^{\circ} \mathrm{C}\right)$, the $\mathrm{H}_{2} \mathrm{~S}$ fugacity is $2.1 \mathrm{kPa}(0.021 \mathrm{~atm})$. This is equivalent to assuming that about half the total sulfur is present as $\mathrm{H}_{2} \mathrm{~S}$. Taking $\mathrm{f}_{\mathrm{H}_{2} \mathrm{O}}$ $=3.95 \mathrm{MPa}(39 \mathrm{~atm})$, the ratio
$\mathrm{H}_{2} \mathrm{O}(\mathrm{g}) / \mathrm{H}_{2} \mathrm{~S}(\mathrm{~g})$ would be 1880 at $523 \mathrm{~K}$. It can then be computed from the free energies of formation in reaction (9) 9,10 that the oxygen fugacity would be of the order of $10^{-31} \mathrm{~Pa}$ $\left(10^{-36} \mathrm{~atm}\right)$.

It has been generally thought that this reducing condition should be maintained, and air kept out of the flowing brine system because the oxidation rates of iron pipes and other metal hardware should be kept as low as possible. However, in view of the severity of the scaling problem, a more oxidized system should be considered if it offers any possibility of increasing the solubilities of scale components.

Reactions (6) through (8) imply that if we made the brine more oxidizing, sulfide scaling could be reduced. There is some experimental evidence to support this hypothesis. Sinclair, ${ }^{11}$ in a study of copper sulfide solubilities in chloride solutions, found that temperature had little effect between 298 and $523 \mathrm{~K}$, while increasing chloride activity, decreasing $\mathrm{pH}$, and increasing oxygen fugacity all enhanced solubility. He concluded that the important copper-containing species at $523 \mathrm{~K}$ was $\mathrm{CuCl}_{3}=$. Oxygen was assumed to enter into the solubility through the formation of sulfate, as in 
reaction (10), which is the sum of reactions (3), (5), (6), (7), and (8). $\frac{1}{2} \mathrm{Cu}_{2} \mathrm{~S}+3 \mathrm{Cl}^{-}+\mathrm{O}_{2}$

$$
=\mathrm{CuCl}_{3}=\frac{1}{2} \mathrm{SO}_{4}^{=} \text {. }
$$

The formation of cupric complexes in Sinclair's experiment was precluded because of the presence of metallic copper.

\section{Oxidation of Sulfur-Containing Species}

The availability of sulfide in solution appears to be the limiting factor in the amount of sulfides that can form in scale. Its oxidation proceeds through numerous reactions, including those of Table 3 , and ultimately producing sulfate.

It is evident that the distribution of sulfur species, the $\mathrm{pH}$, and the oxygen fugacity are all interrelated. A11 of the above oxidation reactions have large equilibrium constants and would proceed far to the right at equilibrium and at this temperature if oxidants were available. However, kinetic considerations may be equally important in a rapidly flowing geothermal fluid. For example, reactions that produce free sulfur do not seem to proceed further, apparently because of fast cooling and kinetic restrictions below about $523 \mathrm{~K} .^{12}$ In fact, after air oxidation free sulfur is seen floating on the brine ponds, ${ }^{13}$ and its precipitation is a common occurrence in the oxidation

Table 3. Equilibrium constants for the oxidation of sulfur species at $523 \mathrm{~K}\left(250^{\circ} \mathrm{C}\right)$ from Helgeson. 6

\begin{tabular}{ll}
\hline Reaction & $\log \mathrm{K}$ \\
\hline $2 \mathrm{H}_{2} \mathrm{~S}+\mathrm{O}_{2}=\mathrm{S}_{2}+2 \mathrm{H}_{2} \mathrm{O}$ & 30.6 \\
$\mathrm{H}_{2} \mathrm{~S}+2 \mathrm{O}_{2}=\mathrm{H}_{-}^{+}+\mathrm{HSO}_{4}^{-}$ & 62.5 \\
$\mathrm{H}_{2} \mathrm{~S}+2 \mathrm{O}_{2}=2 \mathrm{H}^{+}+\mathrm{SO}_{4}^{=}$ & 57.1 \\
$\mathrm{HS}^{-}+2 \mathrm{O}_{2}=2 \mathrm{H}^{+}+\mathrm{SO}_{4}^{=}$ & 64.4 \\
$2 \mathrm{H}^{+}+\mathrm{S}^{=}+1 / 2 \mathrm{O}_{2}=1 / 2 \mathrm{~S}_{2}+\mathrm{H}_{2} \mathrm{O}$ & 31.3 \\
$2 \mathrm{HS}^{-}+\mathrm{O}_{2}+2 \mathrm{H}^{+}=\mathrm{S}_{2}+2 \mathrm{H}_{2} \mathrm{O}$ & 45.3 \\
$\mathrm{~S}+2 \mathrm{O}_{2}=\mathrm{SO}_{4}^{=}$ & 72.7
\end{tabular}


of acidic sulfide solutions. ${ }^{14}$ The $E_{h}$ of the brine stream can be controlled by adjusting the oxygen fugacity, and it should be possible to oxidize $S=$ only as far as free sulfur, without a complete conversion to $\mathrm{SO}_{3}$ or $\mathrm{SO}_{4}=$

The major oxidant demand of the brine would be for complete reaction with iron, copper, sulfur, and manganese species as shown in reactions (18) through (21) of Table 4. Several minor elements such as lead, arsenic, and antimony have not been considered, but are unlikely to affect the conclusions.

Reactions (22) through (25) represent oxidants that might reasonably be added to brine with the following qualifications. It is assumed that enough can be added to buffer the solution. The standard potentials show that none of the substances will oxidize $\mathrm{Mn}^{++}$. $\mathrm{NaOCl}$ is stable and a useful oxidant on1y for alkaline solutions. $\mathrm{FeCl}_{3}$ will not oxidize $\mathrm{Fe}^{++}$.

The reactions have been written in terms of oxygen consumed and produced to simplify the stoichiometry calculations. It would be possible to write out all the combinations from Table 4 to get the formal reactions, which do not involve oxygen, but most of these are of little interest. Several of the composite reactions, however, are informative and are shown in Table 5. Their significance is that under equilibrium conditions, sulfide species will be oxidized first, followed by cuprous copper and, finally, by ferrous iron.

Table 4. Oxidation-reduction reactions in brine.

$$
\begin{aligned}
& \frac{\text { Oxidation }}{4 \mathrm{Fe}^{++}+4 \mathrm{H}^{+}+\mathrm{O}_{2}=4 \mathrm{Fe}^{++}+2 \mathrm{H}_{2} \mathrm{O}} \\
& 4 \mathrm{Mn}^{++}+4 \mathrm{H}^{+}+\mathrm{O}_{2}=4 \mathrm{Mn}^{+++}+2 \mathrm{H}_{2} \mathrm{O} \\
& 2 \mathrm{HS}^{-}+4 \mathrm{O}_{2}=2 \mathrm{H}^{+}+2 \mathrm{SO}_{4}^{=} \\
& 4 \mathrm{Cu}^{+}+4 \mathrm{H}^{+}+\mathrm{O}_{2}=4 \mathrm{Cu}^{++}+2 \mathrm{H}_{2} \mathrm{O}
\end{aligned}
$$

Reduction

$$
\begin{aligned}
& 2 \mathrm{Cl}_{2}+2 \mathrm{H}_{2} \mathrm{O}=4 \mathrm{HCl}+\mathrm{O}_{2} \\
& 4 \mathrm{HNO}_{3}=4 \mathrm{NO}+2 \mathrm{H}_{2} \mathrm{O}+3 \mathrm{O}_{2} \\
& 2 \mathrm{NaOC1}=2 \mathrm{NaCl}+\mathrm{O}_{2} \\
& 4 \mathrm{FeCl}_{3}+2 \mathrm{H}_{2} \mathrm{O}=4 \mathrm{FeCl}_{2}+4 \mathrm{HCl}+\mathrm{O}_{2}
\end{aligned}
$$


Table 5. Sulfur-copper-iron interactions at $523 \mathrm{~K}\left(250^{\circ} \mathrm{C}\right) .^{6}$

$\log \mathrm{K}$

$\begin{array}{lr}8 \mathrm{Fe}^{+++}+4 \mathrm{H}_{2} \mathrm{O}+\mathrm{S}=8 \mathrm{Fe}^{++}+\mathrm{SO}_{4}^{=}+8 \mathrm{H}^{+} & 71.9 \\ 8 \mathrm{Cu}^{++}+4 \mathrm{H}_{2} \mathrm{O}+\mathrm{S}^{=}=8 \mathrm{Cu}^{+}+\mathrm{SO}_{4}^{=}+8 \mathrm{H}^{+} & 19.6 \\ \mathrm{Cu}^{+}+\mathrm{Fe}^{++}=\mathrm{Cu}^{++}+\mathrm{Fe}^{++} & 6.6\end{array}$

If we assume a brine that contains about 3 ppm copper, $30 \mathrm{ppm}$ sulfur, $1030 \mathrm{ppm}$ iron, and $1140 \mathrm{ppm}$ manganese, it can be computed from reactions (18) through (21) that the total oxidant demand could be equivalent to $375 \mathrm{ppm}$ oxygen. This could, in principle, be supplied simply by the injection of oxygen gas. However, in view of the very short time available for chemical reaction in this system, alternate oxidants may prove more useful. From Eqs. (22) through (25), $1660 \mathrm{ppm} \mathrm{C1}_{2}, 980 \mathrm{ppm}$ $\mathrm{HNO}_{3}, 1740 \mathrm{ppm} \mathrm{NaOCl}$, or $4580 \mathrm{ppm}$ $\mathrm{FeCl}_{3}$ would be sufficient. These quantities should be considered as guides only. The actual amounts required are difficult to estimate. It would seem advisable to supply excess reagents wherever possible, because of uncertainties as to completeness of mixing and reaction kinetics. It does not seem possible at this time to predict the kinetics of redox reactions in a system as complex as a hot brine.

An alternate oxidation process would make indirect use of atmospheric oxygen. After the spent brine is exposed to air, the ferrous iron is oxidized to ferric iron. A small percentage of this solution could be recycled into the brine stream at the cost of filtering, reheating, and pumping it. The $\mathrm{Fe}^{+++}$could then be used to oxidize the $s=$

$$
\mathrm{S}=+2 \mathrm{Fe}^{+++}=\mathrm{S}+2 \mathrm{Fe}^{++} \text {. }
$$

The effect of a few parts per million of sulfur in the brine stream is not obvious. It will be a liquid down to about $393 \mathrm{~K}\left(120^{\circ} \mathrm{C}\right)$. If it remains colloidal after solidification, it might well pass through expansion tubes and turbines without collecting. 


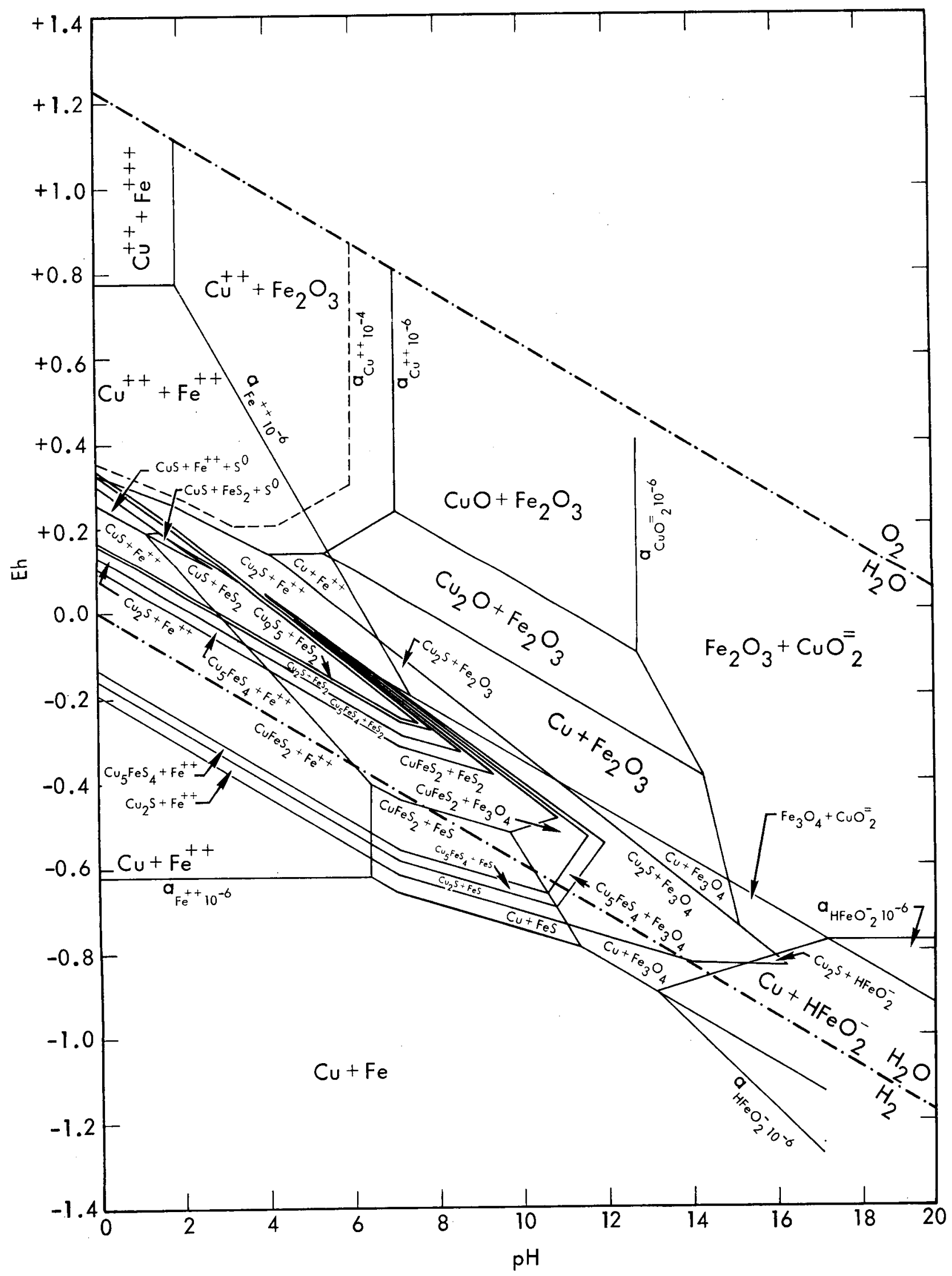

Fig. 3. The system $\mathrm{Cu}-\mathrm{Fe}-\mathrm{S}-\mathrm{O}-\mathrm{H}$ (in part) at $25^{\circ} \mathrm{C}$ and 1 -atm total pressure. Total dissolved sulfur is $10^{-4} \underline{\mathrm{M}}$. 


\section{Solubilities of Copper and Iron Compounds}

Although an oxidation process appears useful in reducing sulfide formation, the possibility must be considered that other solid phases such as oxides, hydroxides, and sulfates might be precipitated at higher oxygen fugacities.

The relatively high concentration of iron probab1y makes it of most concern in this respect. If, as previously suggested, excess oxidants were added and iron were oxidized to the ferric state, it might again become insoluble. At this temperature, chloride concentration, and $\mathrm{pH}$, the stoichiometric ion activity coefficient $\gamma$ for $\mathrm{Fe}^{+\mathrm{H}}$ is estimated ${ }^{6}$ to be about $10^{-8}$. If the $\log \mathrm{K}_{\mathrm{eq}}$ for reaction (30) is 10.86 , it can be calculated that precipitation would occur at a total iron concentration of about $3 \times 10^{-12} \underline{\mathrm{M}}$, which is far below its actual value from Table 1 . $2 \mathrm{Fe} e^{+H}+3 \mathrm{H}_{2} \mathrm{O}=\mathrm{Fe}_{2} \mathrm{O}_{3}+6 \mathrm{H}^{+}$.

This would indicate that the addition of excess oxidants is not desirable.
It is also evident from reaction (30)

that such precipitation might be avoided by acidification of the brine. However, a calculation shows that this would require lowering the $\mathrm{pH}$ to about 1.3, which does not appear practica1.

The same phenomena can be visualized with the help of a Pourbaix (or $\mathrm{E}_{\mathrm{h}}-\mathrm{pH}$ diagram) as shown in Fig. 3. ${ }^{15}$ This example has been constructed for $298 \mathrm{~K}\left(25^{\circ} \mathrm{C}\right)$ and so is more representative of equilibria with spent brine than with wellhead brine. Similar diagrams for higher temperatures are not available, but could be constructed from tabulated data. ${ }^{6}$

It can be seen that at a pH of 4.6 and in the bornite-pyrite field, we are at an $E_{h}$ of about -0.15 . As the solution is made more oxidizing, iron and copper become more soluble provided the $\mathrm{pH}$ is kept low enough to avoid the precipitation of oxide phases.

\section{Solubilities of Barium and Calcium Compounds}

It is necessary to consider the consequences of possible increases in sulfate from the oxidation process.
Although $\mathrm{Fe}^{++}$sulfates are soluble, it is possible that such materials as $\mathrm{BASO}_{4}$ and $\mathrm{CaSO}_{4}$ could be precipitated. 
Their approximate solubilities in $5 \underline{M}$ chloride solutions are given in Table 6.

In the case of $\mathrm{BaSO}_{4}$, the sulfate complexing effect of calcium in the brine has been neglected. $\mathrm{CaSO}_{4}$ ion pairs are formed that enhance $\mathrm{BaSO}_{4}$ solubility. Also, the possible effects of carbonate complexing of both elements were not considered.
The data show, however, why these sulfates do not occur in scale if the norma1 $\mathrm{SO}_{4}^{=}$is less than $1 \mathrm{ppm}$. If more than $10 \%$ or so of the total $30 \mathrm{ppm}$ sulfur (90 ppm as $\mathrm{SO}_{4}^{=}$) is oxidized to $\mathrm{SO}_{4}^{=}$, precipitation is possible. However, a partial oxidation process will not necessarily cause solid sulfates to form.

Table 6. Sulfate solubilities.

\begin{tabular}{cccccc}
\hline Element & Temperature & $\begin{array}{c}\text { Solubility, } \\
\text { moles/litre }\end{array}$ & $\begin{array}{c}\text { Required ppm } \\
\text { So }{ }_{4} \text { for } \\
\text { precipitation }\end{array}$ & Reference \\
\hline \multirow{2}{*}{$\mathrm{Ba}$} & 373 & 100 & 0.00065 & 8.0 & 16 \\
& 523 & 250 & 0.0011 & 24.0 & 16 \\
$\mathrm{Ka}$ & 373 & 100 & 0.032 & 23.8 & 17 \\
& 523 & 250 & 0.016 & 6.0 & 17 \\
\hline
\end{tabular}

\section{Summary}

It appears that there is a reasonable possibility of reducing or eliminating that part of the scaling that is caused by sulfides, through a partial oxidation or combined oxidation-acidification process. Although excess reagents would be desirable to ensure sulfur oxidation, it is possible that this could cause the precipitation of oxides and sulfates. No more definite statement can be made at this time for several reasons. The natural brines are chemically more complex than simple chloride solutions. There are uncertainties of unknown magnitude in the available thermodynamic data. The expansion and cooling occur rapidly, and precipitation is very much a kinetically controlled process. In view of these circumstances, experimental chemical modification of samples of flowing brine at the wellhead is likely to prove most useful in verifying scale control processes. 


\section{References}

1. L. B. Owen, Precipitation of Amorphous Silica from High-Temperature Hypersaline Geothermal Brines, Lawrence Livermore Laboratory, Rept. UCRL-51866 (June 1975).

2. B. J. Skinner, D. E. White, H. J. Rose, and R. E. Mays, "Sulfides Associated with the Salton Sea Geothermal Brine," Econ. Geol. 62, 316-330 (1967).

3. D. E. White, "Environments of Generation of Some Base-Metal Ore Deposits," Econ. Geo1. 63 (4), 301-335 (1968).

4. H. C. Helgeson, "Geologic and Thermodynamic Characteristics of the Salton Sea Geothermal System," Amer. J. Sci., 129-149 (1968).

5. G. K. Czamanske, "Sulfide Solubility in Aqueous Solutions," Econ. Geo1. 54, 57-63 (1959).

6. H. C. Helgeson, "Thermodynamics of Hydrothermal Systems at Elevated Temperatures and Pressures," Amer. J. Sci., 267, 729-804 (1969).

7. J. H. Hill, Memorandum 75-13 (January 17, 1975), unpublished data.

8. B. J. Skinner, "The System Cu-Ag-S," Econ. Geo1. 61, 1-26 (1966).

9. JANAF Thermochemical Tables, National Bureau of Standards Publication, Rept. NSRDS-NBS 37, 2nd ed. (1971).

10. T. B. Reed, Free Energy of Formation of Binary Compounds (M.I.T. Press, Cambridge, Mass., 1971).

11. W. D. Sinclair, The Solubility of Copper and Copper Sulfides in Aqueous Chloride Solutions from 25 to $250^{\circ} \mathrm{C}$, With Geologic Applications, Ph.D. thesis, University of Wisconsin (1973); Dissertation Abstracts 34 (10), 5032-B (Apri1 1974).

12. H. L. Barnes, "Investigations in Hydrothermal Sulfide Systems," in Research Techniques for High Pressure and High Temperature, G. C. U1mer, Ed. (Springer-Verlag, New York, 1971), Ch. 12.

13. John H. Hill, private communication (Apri1 1975).

14. H. L. Barnes and G. Kullerud, "Equilibria in Sulfur-containing Aqueous Solutions, in the System Fe-S-0, and their Correlation during Ore Deposition," Econ. Geol. 50, 648-688 (1961).

15. R. M. Garrels and C. M. Christ, Solutions, Minerals, and Equilibria (Harper \& Row, New York, 1965). 
16. S. D. Malinin, N. Y. Uchameyshvili, and N. I. Khitarov, "Application of the Theory of Strong Electrolytes to the Solubility of Barite in Aqueous Metal Chlorides under Hydrothermal Conditions," Geokhim. (8), 927-938 (1969).

17. C. C. Templeton and J. C. Rodgers, "Solubility of Anhydrite in Several Aqueous Salt Solutions Between 250 and $325 \mathrm{C}$," I. Chem. Eng. Data 12 (4), 536-547 (1967). 